\title{
Challenges to Family Unity and Opportunities for Promoting Child Welfare in an Increasingly Punitive Immigration Landscape
}

\author{
Megan Finno-Velasquez \\ Alan J. Dettlaff
}

\begin{abstract}
This paper describes specific challenges to family unity and child welfare among children in immigrant families resulting from immigration enforcement. Surges in immigration activity over the past decade have resulted in family economic hardship, psychological trauma to children, and difficulty accessing social services. Children whose parents are detained/deported are at risk of unnecessarily entering the child welfare system, and encounter significant barriers to family reunification. In recent months, the scope of enforcement priorities that previously safeguarded many parents now target a much larger group of immigrants for deportation, increasingly disregarding the needs of children. Immigration raids have terrorized communities across the country, and repercussions are being felt by the child welfare system and social service providers. Within an anti-immigrant political climate, there is a desperate need for social workers to lead initiatives to respond to immigrants' needs. Strategies include: (1) development of social work expertise in working with immigrants; (2) cross-systems and cross-disciplinary collaborations; (3) leveraging existing resources and supports; (4) documentation/collection of data; and (5) focused advocacy efforts.
\end{abstract}

Keywords: Children of immigrants; child welfare; social work

The number of children in immigrant families in the U.S. has risen for the past several decades. By 2015, a full quarter of children in the U.S. were from immigrant families (Clarke, Turner, \& Guzman, 2017). Numbers of unaccompanied children arriving to the U.S. have also spiked in recent years (Rosenblum \& Ball, 2016). In 2016 alone, nearly 250,000 immigrants were deported (U.S. Immigration and Customs Enforcement, 2016). Thousands of unaccompanied children were placed in federal foster care or released to sponsors while awaiting asylum claims. Surges in immigration activity have resulted in family economic hardship, psychological trauma to children, and difficulty accessing social services. Children whose parents have been detained or deported have been at risk of unnecessarily entering the child welfare system, and encounter significant barriers to reunification with their parents. Unprecedented numbers of unaccompanied migrant children arriving to the U.S. in recent years have posed significant challenges for the child welfare system. Once children in immigrant families come to the attention of the child welfare system, they face considerable barriers to achieving positive outcomes.

During the Obama administration, some efforts were made to reduce the risk of collateral consequences of immigration on children. For example, the 2013 ICE Parental Interests Directive protects immigrants' parental rights and responsibilities by increasing detained parent's ability to be involved in child welfare proceedings and arrangement of

Megan Finno-Velasquez, PhD, LMSW, is an Assistant Professor and Director of the Center on Immigration and Child Welfare, School of Social Work, New Mexico State University, Albuquerque, NM 87111. Alan J. Dettlaff, PhD, is Dean and Maconda Brown O'Connor Endowed Dean's Chair for the Graduate College of Social Work at the University of Houston, Houston, TX, 77204. 
care for their children (U.S. Immigration and Customs Enforcement [ICE], 2013). In recent months, however, the scope of enforcement priorities that previously safeguarded many parents now target a much larger group of immigrants for deportation, increasingly disregarding the needs of children. Immigration raids have terrorized communities across the country, and repercussions are being felt by the child welfare system and social service providers throughout the country.

This article describes specific challenges to family unity and child well-being among immigrant children or U.S. citizen children in immigrant families resulting from immigration policy and enforcement activities. Within an anti-immigrant political climate, this paper identifies opportunities for social workers to lead initiatives to respond to this problem, with strategies that include: (1) development of social work expertise in working with immigrants; (2) cross-systems and cross-disciplinary collaborations; (3) leveraging existing resources and supports; (4) documentation/collection of data; and (5) focused advocacy efforts.

\section{Children of Immigrants in the U.S.}

Changes in immigration patterns and trends over the past two decades have considerably shifted the demographic profile of the United States (Grieco et al., 2012). The number of foreign-born immigrants living in the United States has increased, and the proportion of children in the U.S. living in immigrant families has been rising for the past several decades. In 1990, just $8.3 \%$ of children in the U.S were in immigrant families, but by 2015, a full quarter of children were from immigrant families (Annie E. Casey Foundation, 2018).

Approximately 20 percent of children with two parents live with two foreign-born parents, and 10 percent of children live in families of mixed-status parents, or families with one foreign-born and one native-born parent (U.S. Census Bureau, 2017). Almost a third $(30 \%)$ of children of immigrants have at least one undocumented parent (Capps, Fix, \& Zong, 2016), while $90 \%$ of children in immigrant families are themselves U.S. citizens (Annie E. Casey Foundation, 2017). More than half (55\%) of immigrant children are of Hispanic origin, followed by sixteen percent non-Hispanic white, seventeen percent nonHispanic Asian, and nine percent non-Hispanic black (Child Trends Data Book, 2014). Although children of immigrants reside throughout the country, half of children in immigrant families live in 4 states: California, Texas, New York, and Florida Annie E. Casey Foundation, 2017). Rates of children in immigrant families vary widely by state, ranging from $3 \%$ in West Virginia to $48 \%$ in California .

The numbers of unaccompanied children arriving to the U.S. have also spiked in recent years, peaking in 2014 and rising again in 2016 with nearly 60,000 arrivals that year (U.S. Customs and Border Protection, 2016). The greatest numbers of children encountered by U.S. Customs and Border Patrol are arriving from Guatemala, Honduras, and El Salvador, known as the Northern Triangle region of Central America (Chishti \& Hipsman, 2016). The vast majority of unaccompanied children released to approved sponsors are in California, Texas, New York, and Florida. 


\section{Challenges to Family Unity \& Child Well-Being}

Immigration Enforcement and Child Well-being. Immigration enforcement activities conducted by Immigration and Customs Enforcement (ICE) have resulted in an unprecedented number of deportations over the past decade. The period between 2005 and 2008 was characterized by a large increase in enforcement efforts, most notably with several highly publicized worksite enforcement operations (Dettlaff \& Finno-Velasquez, 2013). Major worksite enforcement operations were mostly halted in 2008 with a changing administration and harsh criticism by child advocates. As a result of the attention generated by these raids, ICE developed a set of humanitarian guidelines that applied to enforcement actions involving more than 150 arrests, which was later reduced to actions involving more than 25 arrests (Dettlaff, 2012). Those guidelines encouraged the identification of individuals who are the sole caregivers of minor children or who have other humanitarian concerns, including individuals with serious medical conditions, nursing mothers, pregnant women, or caregivers of spouses or relatives with serious medical conditions. Evidence suggests that when administered appropriately, those guidelines have been effective in preventing or minimizing parent-child separations (Chaudry et al., 2010). The limitation is that those guidelines do not apply to enforcement actions targeting individuals or small groups, including home raids and other small criminal justice operations.

Although worksite raids were suspended under the Obama administration, the Obama administration oversaw the highest number of deportations in recent history. Between 2009 and 2013, almost half a million parents were deported from the United States (American Immigration Council, 2017). In fiscal year 2016 alone, almost a quarter million immigrants were deported (López \& Bialik, 2017). The leading countries of origin for deportations were Mexico, Honduras, Guatemala, and El Salvador (Batalova \& Lesser, 2017). Documented impacts of worksite raids include family economic hardship, psychological trauma to children, difficulty accessing social services because of language barriers, difficulty documenting eligibility, mistrust and fear, and family separation (Campetella et al., 2015).

There are several reasons for this increase in detention and deportation, all of which are associated with interior enforcement operations, such as fugitive operations, small worksite raids, Customs and Border Patrol traffic stops, and increased cooperation between local law enforcement and the Department of Homeland Security (DHS). In 2007, a strategy was adopted to prioritize the apprehension of immigrants who have committed criminal offenses, which resulted in the merging of several programs under the ICE Agreements of Cooperation in Communities to Enhance Safety and Security (ACCESS) initiative. One of the most well-known of these is the $287(\mathrm{~g})$ program, which established collaborations between ICE and local officials that allow local police to be deputized to enforce immigration laws. Currently ICE has 287(g) agreements with 60 law enforcement agencies in 18 states, and ICE officers have certified more than 1,800 local officers to enforce immigration law (U.S. Department of Homeland Security, 2017). A related program, Secure Communities, uses local jails to identify immigrants for deportation by forwarding fingerprint data from the FBI to ICE, which determines the arrested person's immigration status. If the arrested person is identified as a non-citizen, ICE can request that 
local authorities detain that person until ICE moves him or her to an immigration detention center.

Although the stated goal of these programs is the removal of individuals who pose a threat to national security and public safety by prioritizing those with an aggravated felony conviction or multiple felonies, Secure Communities has resulted in the deportation of thousands of immigrants who do not have criminal convictions at all, or whose only crimes are simple misdemeanors such as driving without a license (American Immigration Lawyers Association [AILA], 2011). Secure Communities operates as a partnership between local law enforcement and ICE and is still implemented throughout the country.

In addition to these federal enforcement programs, a number of state and local immigration enforcement initiatives have been fueld by anti-immigrant sentiment, such Arizona's Senate Bill 1070 and other copycat laws. Arizona Senate Bill 1070 (Support our Law Enforcement and Safe Neighbors Act, 2010) imposed penalties on immigrants who failed to provide immigration documentation and allowed law enforcement to ask suspected undocumented immigrants about their immigration legal status. Following the adoption of Arizona's law, many other states considered copycat laws while Utah, Georgia, Indiana, Alabama, and South Carolina passed SB1070-style legislation (Lacayo, 2011). However, Arizona's SB1070 (and others) have since been challenged in court. In 2012 the Supreme Court blocked three of four provisions in the bill as well as in other copycat laws (Liptak, 2012).

Despite the ramping up of enforcement during the Obama administration, some efforts were made to reduce the risk of collateral consequences on children. Advocacy by immigrant rights and child protection groups led to an increased use of prosecutorial discretion to release parents in deportation cases. This resulted in a decrease in removals of parents of children legally present in the U.S. (Trevizo, 2016). In 2011, ICE created policy that directs ICE personnel to avoid arresting individuals at certain "sensitive locations" including churches, schools, and childcare programs (Morton, 2011). Arguably, the largest win for children during the Obama administration was ICE's 2013 Parental Interests Directive, created with the aim of helping ICE balance the enforcement of immigration laws with respect for a parent's/guardian's rights and responsibilities. The Parental Interests Directive contains specific guidelines for the handling of cases involving primary caretakers, parents or legal guardians of minor children, and particularly those involved in family court or child welfare proceedings. It promotes better tracking of immigration cases involving parents, legal guardians, and primary caretakers of minor children. This directive encourages taking children into account when determining detention placement locations, needs for court participation, and allowing for parent-child visitation. As a result, it also increased the ability of detained parents to make decisions for the care of their children and participate in child welfare proceedings. With the implementation of the Parental Interests Directive, while families continued to be separated by immigration enforcement, the chances that a family would become involved with the child welfare system as a result of immigration enforcement decreased.

However, harsh enforcement strategies were again elevated along the border in 2014 when unaccompanied immigrant children began to flee to the United States in large 
numbers to escape violence and persecution in their countries of origin (Kandel, 2017). As a result, the Obama administration publicly committed to an aggressive deterrence strategy which resulted in increased apprehensions of children and individuals seeking asylum from Mexico and other Central American countries (The White House, Office of the Press Secretary [WH OPS], 2014). This surge resulted in an expansion of immigrant detention, including the detention of children and mothers, and increases in the separation of children from their parents when crossing the border (Detention Watch Network, n.d.). Through the Office of Refugee Resettlement, many thousand unaccompanied children are released to parents or relatives willing to sponsor the children while they are waiting for decisions in their immigration cases. As currently funded, the ORR licensing and monitoring process for unaccompanied minor sponsor cases is generally less stringent than the regulation and oversight of state foster care licensing. In most cases, federal protective jurisdiction of unaccompanied children ends after a short home study and release to sponsors. Once released to sponsors, these placements are not subject to any oversight or monitoring, and the children do not have access to health insurance, public assistance, or any health or support services normally afforded to children in state foster care, leaving the placements at risk of disruption, exploitation, and maltreatment.

Impact of Immigration Enforcement on Children and Families. Research documenting the impact of immigration enforcement activities over the past decade suggests that parental detention and deportation results in child trauma and mental health problems, increased family instability, and heightened risk that a family will become involved with the state child welfare system, especially when parents lose their parental rights (Koball et al., 2015). U.S.-citizen children of detained and deported parents experience a greater amount of psychological distress, trauma, and PTSD symptoms than their counterparts with parents who have not been impacted by immigration enforcement (Rojas-Flores, Clements, Koo, \& London, 2017). Children affected by parental detention and deporation also demonstrate higher levels of depression and anxiety, lower academic performance, and greater behavioral problems (Rojas-Flores et al., 2017). Furthermore, Dreby (2012) found that children in Latino immigrant families experience significant negative outcomes not only due to the fear of immigration enforcement, but also because of ethnic identity challenges and stigma and conflation of ICE with law enforcement.

Not only does immigration enforcement negatively affect children, but it also affects the entire family system. In one study, spouses and partners reported increased feelings of depression and social isolation, which is associated with negative cognitive and behavioral outcomes in children (Koball et al., 2015). The loss of income from a detained or deported family member contributes to family financial insecurity, housing and related food insecurity, and lack of access to social services due to fear of interacting with government officials (Brabeck, Sibley, \& Lykes, 2016; Dreby, 2012). The many burdens of immigration enforcement including financial distress, stressful events, and social isolation, are factors associated with child maltreatment and involvement with the child welfare system (Dettlaff \& Finno-Velasquez, 2013).

The Current Climate. The concerns for children resulting from family separation and immigration enforcement have escalated since the 2016 presidential election. In recent months, the scope of enforcement priorities that previously safeguarded many parents now 
target a much larger group of immigrants for deportation, increasingly disregarding the needs of children. Shortly after taking office, the Trump administration issued two executive orders that authorized a new list of immigration enforcement priorities expanding removability to include anyone who has committed an act constituting a chargeable offense, such as entering the country illegally, which placed nearly 11 million undocumented individuals and many legal permanent residents at risk of deportation (WH OPS, 2017). Since that time, the nation has seen ramped up activity by ICE in communities across the country.

In 2017, the Trump administration proposed a new deterrence strategy that included systematically separating children crossing borders from their parents and placing them into foster care (Ainsely, 2017). Public outcry put a stop to this border deterrence initiative, but the impacts of ramped up enforcement are still felt (Foley \& Planas, 2017). In fact, although it has not received much press, the separation of children and parents at the border has occurred to some degree since the Obama administration (AILA, 2016). With very limited options for family detention, parents and children are often held in separate facilities (Barrick, 2016). Reports have also surfaced of pregnant women seeking asylum being held in detention with risks to their unborn children's health, in violation of ICE's own policy (Bogado, 2014). Asylum claims by people fleeing violence and persecution in Mexico and other Central American countries are no longer being granted (Dickerson \& Jordan, 2017). Reports of suicidal ideation and attempt among detained women and their children have emerged.

In July of 2017, the Trump administration also announced that it will begin arresting and deporting undocumented parents, guardians, and relative sponsors of unaccompanied children (Burke, 2017). The effects of this policy exacerbate the chances that unaccompanied children will be placed in state child welfare custody. Not only does this policy punish individuals who have in good faith come forward to care for unaccompanied children, but it will also leave children with fewer relative and kin options for sponsors, placing them at higher risk of disruption in placement and increased risk for entry into state foster care.

Immigration Enforcement and Risk for Child Welfare Involvement. Although an emerging body of research has begun to shed some light on the involvement of immigrant children and families in the child welfare system, the extent to which immigration enforcement activities have contributed to child welfare system involvement remains unknown. One study estimated that in 2011 as many 5,100 children currently in foster care have parents who have been either detained or deported (Wessler, 2011). Although that study could not determine whether these children entered foster care as a direct result of their parents' detention or deportation, anecdotal information suggests that this problem is likely to grow as a result of recent changes to immigration enforcement policies.

Although the exact number of children who become involved in the child welfare system as a result of immigration enforcement is unknown, it is clear that children have been impacted by these efforts. Statistics made available from DHS in late 2012 showed that between July 1, 2010, and September 30, 2012, DHS removed 204,816 parents of U.S. citizen children from the United States (U.S. Department of Homeland Security, 2012) In 
2013, ICE conducted 72,410 removals of parents with at least one U.S. citizen child (Foley, 2014). No data have been made public on the whereabouts of the children from these families or the consequences they faced as a result of their parents' deportation.

The challenges of cases involving children who enter the child welfare system due solely to an immigrant parent's arrest or apprehension are far-reaching. Although courts that handle child welfare cases operate under statutes requiring that children's best interests be considered in decisions regarding their custody and placement (Child Welfare Information Gateway, 2010), there are wide variations across juvenile courts in what is interpreted to be in children's best interest when parents are deported. Immigration law does not recognize children's interests as a valid factor in the immigration decisions concerning their parents, which can lead to profound implications for families with mixed immigration statuses. Children may remain in the United States and be permanently separated from their parents - or they can leave their home and all they have known to move to an unfamiliar country to remain with their family. Although this has been described as a "choiceless choice" for immigrant parents (Thronson, 2006), best practice calls for deported parents' decisions regarding their children to be honored when maltreatment is absent. However, the extent to which parents' and children's voices are heard in juvenile court decisions remains unknown.

Parents detained in immigration facilities may be prevented from meaningfully participating in a court plan for reunification. In some cases, child welfare staff are unable to locate parents, reducing their chances of participation in decisions concerning their children, including court proceedings related to their children's care and custody. Deportation proceedings and decisions often last longer than the timeframes under which child welfare agencies must make decisions about children's permanency, further complicating the agencies' ability to act in children's best interests (Cervantes \& Lincroft, 2010).

Child Welfare System Challenges. Regardless of how or when children of immigrants come into contact with the child welfare system, social workers face complex challenges to responding to their needs and facilitating positive outcomes related to their safety, permanence, and well-being. Research has shown that children with immigrant parents who become involved with child welfare systems have lower access to mental health services than children with U.S. citizen parents (Dettlaff \& Cardoso, 2010; FinnoVelasquez, Cardoso, Dettlaff \& Hulburt, 2015). Immigrant parents who become involved with the child welfare system also have less access than non-immigrant parents to needed substance abuse services and concrete supports that can prevent entry of their children into foster care (Finno-Velasquez, 2013; Finno-Velasquez, Seay \& He, 2016).

Once children enter foster care, immigration status can create additional delays or barriers to reunification, as non-citizen parents may be unable to obtain employment or participate in certain mandated services or supportive services that could facilitate reunification (Dettlaff \& Fong, 2016). Language barriers can result in miscommunication and misunderstandings, and delays in service delivery, which can affect parents' abilities to complete required services and place them at risk for termination of parental rights due 
to the timeframes mandated by the Adoption and Safe Families Act (ASFA) of 1997 (Ayón, 2009; Committee for Hispanic Children and Families, 2003).

Child welfare workers may also encounter challenges in the placement of children of immigrants. In many states, undocumented immigrant family members do not qualify to serve as foster parents for children because of their legal status (Ayón, Aisenberg, \& Cimino, 2013; Wessler, 2011). Child welfare workers must also attempt to locate relatives residing in other countries to notify and screen for potential placement. Sometimes, when parents reside in other countries, reunification plans must cross transnational borders, requiring coordination of home studies and services with foreign governments (Lincroft \& Borelli, 2009; Reed \& Karpilow, 2009). Many children and their family members involved with child welfare agencies also qualify for some form of immigration relief, and their ability to obtain legal status depends on the child welfare system's capacity to adequately screen for eligibility and navigate the immigration system, ideally in collaboration with immigration experts (Finno \& Bearzi, 2010). Some child welfare agencies across the country have solid partnerships and policies in place to provide those assessments and ensure that immigrant children and families receive due process, but many still do not (Lincroft, 2013).

Another challenge is the lack of expertise within the child welfare workforce about the unique needs of immigrant families that result from their experiences with immigration and acculturation. Achieving reunification with parents largely depends on the child welfare system's ability to provide family services that effectively address the issues that led to this placement, as well as the parents' participation and engagement in these services (Dettlaff \& Fong, 2016). Given these barriers, immigrant families may be at a disadvantage in meeting case requirements and reunifying children with family members, thus placing them at greater risk for termination of parental rights.

Since the beginning of the Trump administration, immigration policy has taken a strikingly different direction, with almost unilateral disregard for the well-being of children. The scope of enforcement priorities that previously safeguarded many parents and long-time residents whose only violation was living in the country without documentation now target a much larger group of immigrants for deportation. Immigration raids have taken place in communities across the country, and its consequences are being felt by social workers and their immigrant clients throughout the country. The impact of enforcement activities on child welfare systems is not yet known, but it is widely feared that children's well-being and stability continue to be compromised.

\section{Directions for Social Work}

The following are approaches that the profession of social work can take to respond to immigrants' needs: (1) development of social work expertise in working with immigrants; (2) cross-systems and cross-disciplinary collaborations; (3) leveraging existing resources and supports; (4) documentation/collection of data; and (5) focused advocacy efforts.

Development of social work expertise in immigration. First, the profession of social work must develop specific expertise in practice with immigrants. In addition to competence in working with ethnically and culturally diverse groups, as professionals who 
work across disciplines, various aspects of the immigration system and immigration law that affect families' lives should be seamlessly integrated into required social work training curricula. Training is needed that provides information to social workers, especially those working in the child welfare field, on the experiences of immigrant children and families to improve cultural responsiveness and reduce the potential for bias. To conduct adequate assessments and provide interventions that respond to their needs, child welfare professionals need to understand the effects of immigration and acculturation on immigrant family systems. Once children in immigrant families become involved in the child welfare system, social workers need to be familiar with resources and programs available for immigrant children and families to provide comprehensive services that meet their needs. Practitioners also need to be familiar with federal and state policies that affect immigrant and refugee children and families and understand how those policies may affect service delivery. Within child welfare systems especially, it is important to develop, recruit, and train social workers who are bilingual and bicultural in order to respond more appropriately to children and families from diverse cultures. Bridging Refugee Youth and Children's Services (BRYCS) offers a number of training tools and webinars on their website that can assist social workers working wtih refugee families, and specifically, refugee children and adolescents, on a number of issues (i.e., trauma, accessing resources, navigating the legal system, etc.). The website for the Immigration Legal Resource Center offers multiple trainings relevant to social workers that are specific to immigration laws. The NASW California chapter offers multiple low-cost courses on their website, including one specific to immigration and child welfare issues. Both courses are designed to provide social workers with information about current U.S. immigration laws and the impact of immigration enforcement on children and families. Improved understanding of immigration policy and culture can lead to improved engagement, more thorough assessments, and more effective service delivery.

Cross systems and cross-disciplinary collaborations. Effective social work practice with immigrant children and families cannot be achieved in isolation. Many immigrant families are likely to intersect with multiple systems, and a coordinated community response is necessary to promote their overall well-being. Within the current environment over the past several months, many grass-roots initiatives have begun in various states and localities around the country to protect immigrant children and families. These include rapid response teams and networks in many states including California, Colorado, Massachusetts, and Virginia that are composed of social workers, attorneys, advocates, and community organizers who offer support particularly in the wake of immigration raids, which often leave children behind (Spivack, 2017). Social workers are the ideal professionals to engage with various systems and ensure all key stakeholders have a place at the table, as issues around immigration and child welfare are complicated, and if successful, will have multiple layers to any response. Collaborations should include foreign consulates and child welfare agencies, legal professionals, public policy and child development experts, courts, schools, health and mental health systems, along with natural supports like churches and faith groups, and academics/research scientists.

Given concerns resulting from ongoing immigration enforcement efforts, social work professionals, and child welfare agencies in particular, need to develop and strengthen 
relationships within immigrant communities to create a climate where families feel safe accessing services and the reporting of maltreatment can take place without fear of deportation or other negative consequences to families. Child welfare agencies in particular should develop collaborations with community-based social service providers in immigrant communities to facilitate education about cultural norms related to maltreatment and to dispel fears about reporting.

Leverage existing resources and supports. For social work professionals and agencies struggling with how to respond, many resources already exist. Advocacy groups around the country have been quick to respond in creating toolkits and legal guides, such as family safety planning and trauma response resources, in response to immigration policy changes. Many such resources are highlighted and can be accessed on the webpage of the Center on Immigration and Child Welfare (2017). Two timely and relevant resources include Appleseed's (2017) updated Protecting Assets and Child Custody in the Face of Deportation: A Guide for Practitioners Assisting Immigrant Families and the Institute for Women in Migration's (IMUMI; 2017) A Brief Guide for Families, Organizations, and Public Officials: Resources To Inform, Support, And Prepare Families for a Possible Return to Mexico. For social workers working in macro settings, energy should focus on translating and disseminating the newest and most relevant research and resources into practice settings, and developing tools and workshops for front-line workers requesting guidance on working with immigrant children and families in the current climate. Plans should focus on using existing training opportunities to increase capacity and skill in working on immigration issues, such as Title IV-E training for child welfare workers, creating a natural platform for disseminating current knowledge into relevant practice.

Documentation and collection of data. In the modern era of data-driven decisionmaking, one of the greatest challenges to proposing solutions is that there is no accurate data on the number of immigrant children and families impacted by deportation and at risk for child welfare system involvement. Nativity and citizenship status has never been uniformly collected across child welfare systems in the U.S., and the Department of Homeland Security does not collect (or publicly release) information on the children of immigrants who are detained and deported. Congressional members have demanded that Homeland Security begin to release this information (Gillibrand et al., 2017). Social workers should continue to push this issue with legislators to continue this pressure. Immigration information is not required for national child abuse and neglect data collection and reporting, and is thus not collected in a consistent manner across the country. There are rightly confidentiality concerns and apprehension about how such information would be used by federal agencies if it were required. However, without a requirement for collecting immigration information, child welfare agencies do not have a way to ensure that immigrant children and families receive the services they need. With no guidance on how to track children in immigrant families, child welfare agencies also grapple with the most sensitive ways to retrieve and record that information from families. Clear protocols should be developed to dictate how to collect sensitive identifying information from immigrants while ensuring the utmost confidentiality of that information for use within the child protection system only. As it currently stands, without official data identifying immigrant families impacted by deportation and involved with the child welfare system, 
efforts to document immigrant family experiences and needs through rigorous research, data collection, community needs assessments, and service evaluations are sorely lacking.

Much additional research is also needed to facilitate the provision of culturally responsive child welfare services. Although some research has begun to identify the presence of immigrant children and families in the child welfare system (Wessler, 2011), specific studies are needed that provide information on interventions that facilitate positive outcomes of safety, permanency, and well-being for immigrant children and families. Interventions that have historically been used with non-immigrant populations may not be effective with immigrant children and families due to their cultural differences, as well as differences in the underlying issues that brought them to the attention of this system. In order to facilitate positive outcomes, interventions need to consider the cultural influences and experiences in immigrant families and how these influences affect service delivery.

Focused Advocacy Efforts. Advocacy is a primary skill of social work practitioners, but now more than ever, all social workers who work with immigrant families, whether in clinical settings, in legal or policy settings, or in research, must include advocacy as part of their responsibilities. Advocacy efforts should focus on electing candidates who support pro-immigrant integration policies, in contrast to restrictive immigration policies, and may include forming local coalitions to respond to community-specific needs and issues. Social workers have an ethical responsibility to understand current policy and report cases of noncompliance with immigration policies to appropriate authorities. Immigrants involved in legal immigration proceedings do not have the right to an attorney, and if they do not have representation, the court will likely not rule in their favor. As part of these advocacy efforts, social workers can help obtain legal representation for immigrant. Multidisciplinary rapid response teams and networks can help provide coordinated and comprehensive responses to immigration raids and other emergency immigration situations (National Immigration Law Center, 2007). Safety and contingency planning resources and trainings in relevant languages are also crucial for immigrant families in order to make practical and legal arrangements in the case of parental detention or deportation (Immigrant Legal Resource Center, 2017). In the current political climate where comprehensive immigration reform remains unlikely, state and local level policy change presents greater promise. Several effective models already exist, such as California's SB 1064 and other collaborative efforts along with border region involving agencies on the U.S. and Mexico sides of the border (Finno \& Bearzi, 2010; Lincroft, 2013). Finally, the narrative around immigration and immigrants in this country has always ebbed and flowed around dominant U.S. values, morals, and who is considered to be deserving and undeserving. As professional social workers, we must use our voices to contribute to framing the public narrative around immigration enforcement as a humanitarian crisis characterized by egregious violations to women's and children's rights.

\section{Conclusion}

With the scope of immigration policy placing the well-being of our children at an unprecedented crossroads, social workers have an ethical obligation to step up and do everything within their power to mitigate or alleviate the traumatic threats and potentially irreparable damage to child well-being imposed by our immigration system. Efforts to 
increase the capacity of social workers to address the unique needs of this population, as well as cross-systems collaborations, and focused advocacy efforts are essential components of this response to facilitate positive outcomes of safety, permanency, and well-being. Specific training on immigration policy and culturally informed, traumasensitive practice with immigrants needs to be prioritized in social work curricula. Field placements for social workers in unconventional settings such as immigration legal clinics and faith-based non-profits that serve immigrants should be developed. In sum, the social work field must improve our ability to meet the needs of immigrant children and families of the modern day U.S.

\section{References}

Ainsely, J. E. (2017, March 3). Exclusive: Trump administration considering separating women, children at Mexico border. Retrieved from Reuters website http://www.reuters.com/article/us-usa-immigration-children/exclusive-trumpadministration-considering-separating-women-children-at-mexico-borderidUSKBN16A2ES?feedType=RSS\&feedName=topNews\&utm_source=twitter\&utm medium $=$ Social

American Immigration Council. (2017, May 28). U.S. citizen children impacted by Immigration Enforcement. Retrieved from https://www.americanimmigrationcouncil.org/research/us-citizen-children-impactedimmigration-enforcement

American Immigration Lawyers Association [AILA]. (2011). Immigration enforcement off target: Minor offenses with major consequences (Report No. 11081609). Retrieved from https://www.aila.org/File/Related/11081609.pdf

AILA. (2016, October 12). Featured issue: Family detention. Retrieved from http://www.aila.org/advo-media/issues/enforcement/detention.

Annie E. Casey Foundation. (2018). KIDS COUNT data center: Children in immigrant Families. Retrieved from http://datacenter.kidscount.org/data/tables/115-children-inimmigrantfamilies?loc=1\&loct=1\#detailed/1/any/false/870,573,869,36,868/any/445,446

Appleseed. (2017). Protecting assets and child custody in the face of deportation: A guide for practitioners assisting immigrant families. Retrieved http://www.appleseednetwork.org/wp-content/uploads/2015/10/Protecting-AssetsAnd-child-Custody-In-The-Face-Of-Deportation-A-Guide-for-PractitionersAssisting-Immigrant-Families-2012.pdf

Ayón, C. (2009). Shorter time-lines, yet higher hurdles: Mexican families' access to child welfare mandated services. Children and Youth Services Review, 31, 609-616. doi: https://doi.org/10.1016/j.childyouth.2008.11.004

Ayón, C., Aisenberg, E., \& Cimino, A. (2013). Latino families in the nexus of child welfare, welfare reform, and immigration policies: Is kinship care a lost opportunity? Social Work, 58(1), 91-94. doi: https://doi.org/10.1093/sw/sws014 
Barrick, L. (2016, August 31). Special report: Adivided by detention: Asylum-seeking families' experiences of Separation. Washington, D.C.: American Immigration Council. Retrieved from https://www.americanimmigrationcouncil.org/research/divided-by-detention-asylumseeking-families-experience-of-separation

Batalova, J., \& Lesser, G. (2017, April 5). Central American immigrants in the United States. Washington, D.C.: Migration Policy Institute. Retrieved from http://www.migrationpolicy.org/article/central-american-immigrants-united-states

Bogado, A. (2014, July 28). ICE detains pregnant women against its own policy. Retrieved from Colorlines website http://www.colorlines.com/articles/ice-detainspregnant-women-against-its-own-policy

Brabeck, K. M., Sibley, E., \& Lykes, M. B. (2016). Authorized and unauthorized immigrant parents: The impact of legal vulnerability on family contexts. Hispanic Journal of Behavioral Sciences, 38, 3-30. doi: https://doi.org/10.1177/0739986315621741

Burke, G. (2017, June 30). Feds will now target relatives who smuggled in children. Retrieved from The Associated Press website https://apnews.com/291d565801984005886f5a22c800fee6/Feds-will-now-target-re

Campetella, A., Capps, R., Hooker, S., Koball, H., Pedroza, J. M., \& Perreira, K. (2015). Research report: Implications of immigration enforcement activities for the wellbeing of children in immigrant families. Washington, D.C.: Migration Policy Institute and Urban Institute. Retrieved from https://www.urban.org/sites/default/files/alfresco/publicationexhibits/2000405/2000405-Implications-of-Immigration-Enforcement-Activities-forthe-Well-Being-of-Children-in-Immigrant-Families.pdf

Capps, R., Fix, M., \& Zong, J. (2016, January). Fact sheet: A profile of U.S. children with unauthorized immigrant parents. Retrieved from the Migration Policy Institute website https://www.migrationpolicy.org/research/profile-us-children-unauthorizedimmigrant-parents

Center on Immigration and Child Welfare. (2017). Resources for social workers. Retrieved from http://cimmcw.org/resources/practice/social-workers/

Cervantes, W., \& Lincroft, Y. (2010). The impact of immigration enforcement on child welfare. Washington, DC: First Focus. Retrieved from https://firstfocus.org/wpcontent/uploads/2010/04/Caught-Between-Systems-Enforcement.pdf

Child Welfare Information Gateway. (2010). Determining the best interests of the child: Summary of state statutes. Retrieved from http://www.childwelfare.gov/systemwide/laws_policies/statutes/best_interest.cfm

Child Trends Data Book. (2014). Immigrant children: Indicator of child and youth wellbeing. Retrieved from https://www.childtrends.org/?indicators=immigrant-children 
Chishti, M., \& Hipsman, F. (2016). Increased Central American migration to the United States may prove an enduring phenomenon. Washington, D.C.: Migration Policy Institute. Retrieved from https://www.migrationpolicy.org/article/increased-centralamerican-migration-united-states-may-prove-enduring-phenomenon

Chaudry, A., Capps, R., Pedroza, J. M., Castaneda, R. M., Santos, R., \& Scott, M. M. (2010). Facing our future: Children in the aftermath of immigration enforcement. Washington, DC: Urban Institute. Retrieved from http://www.urban.org/publications/412020.html

Clarke, W., Turner, K., \& Guzman, L. (2017). One quarter of Hispanic children in the United States have an unauthorized immigrant parent. National Research Center on Hispanic Children \& Families (No. 2017-28). Retrieved from http://www.hispanicresearchcenter.org/publications/one-quarter-of-hispanic-childrenin-the-united-states-have-an-unauthorized-immigrant-parent/

Committee for Hispanic Children and Families. (2003). Creating a Latino child welfare agenda: A strategic framework for change. New York: Author. Retrieved form http://www.chcfinc.org/wp-content/uploads/2014/04/8.-CHCF-Creating-a-LatinoChild-Welfare-Agenda-A-Strategic-Framework-for-Change-July-15-2003.pdf

Detention Watch Network. (n.d.) Family detention: The unjust policy of locking up immigrant mothers with their children. Retrieved from https://www.detentionwatchnetwork.org/issues/family-detention

Detlaff, A. (2012). Immigrant children and families and the public welfare system: Considerations for legal systems. Juvenile \& Family Court Journal, 63(1), 19-30. doi: https://doi.org/10.1111/j.1755-6988.2011.01069.x

Dettlaff, A. J., \& Cardoso, J. B. (2010). Mental health need and service use among Latino children of immigrants in the child welfare system. Children and Youth Services Review, 32, 1373-1379. doi: https://doi.org/10.1016/j.childyouth.2010.06.005

Dettlaff, A. J., \& Finno-Velasquez, M. (2013). Child maltreatment and immigration enforcement: Considerations for child welfare and legal systems working with immigrant families. Children's Legal Rights Journal, 33(1), 37-63.

Dettlaff, A. J., \& Fong, R. (2016). Practice with immigrant and refugee children and families in the child welfare system. In A. J. Detlaff \& R. Fong (Eds.), Immigrant and refugee children and families: Culturally responsive practice (pp. 285-317). New York, NY: Columbia University Press. doi: https://doi.org/10.7312/dett17284

Dickerson, C., \& Jordan, M. (2017, May 3). 'No asylum here': Some say U.S. border agents rejected them. Retrieved from The New York Times website https://www.nytimes.com/2017/05/03/us/asylum-bordercustoms.html?\&hp\&action=click\&pgtype=Homepage\&clickSource=storyheading\&module=second-column-region \&region=top-news\&WT.nav=topnews\& $\mathrm{r}=0$ 
Dreby, J. (2012). The burden of deportation on children in Mexican immigrant families. Journal of Marriage and Family, 74, 829-845. DOI:10.1111/j.17413737.2012.00989.x

Finno, M., \& Bearzi, M. (2010). Child welfare and immigration in New Mexico: Challenges, achievements, and the future. Journal of Public Child Welfare, 4(3), 306324. doi: https://doi.org/10.1080/15548732.2010.496079

Finno-Velasquez, M. (2013). The relationship between parent immigration status and concrete support service use among Latinos in child welfare: Findings using the National Survey of Child and Adolescent Well-being (NSCAWII). Children and Youth Services Review, 35(12), 2118-2127. doi: https://doi.org/10.1016/j.childyouth.2013.10.013

Finno-Velasquez, M., Cardoso, J. B., Dettlaff, A. J., \& Hulburt, M. S. (2015). Effects of parent immigration status on mental health service use among Latino children referred to child welfare. Psychiatric Services, 67(2), 192-198. doi: https://doi.org/10.1176/appi.ps.201400444

Finno-Velasquez, M., Seay, K. D., \& He, A. S. (2016). A national probability study of problematic substance use and treatment receipt among Latino caregivers involved with child welfare: The influence of nativity and legal status. Children and Youth Services Review, 71, 61-67. doi: https://doi.org/10.1016/j.childyouth.2016.10.035

Foley, E. (2014, June 26). Deportation separated thousands of U.S.-born children from parents in 2013. Retrieved from HuffPost website https://www.huffingtonpost.com/2014/06/25/parents-deportation_n_5531552.html

Foley, E., \& Planas, R. (2017, April 5). Trump administration won't routinely separate families at the border after all. Retrieved from http://www.huffingtonpost.com/entry/dhs-separating-familiesborder us $\underline{58 \mathrm{e} 50 \mathrm{~d} 4 \mathrm{fe} 4 \mathrm{~b} 0 \mathrm{f} 4 \mathrm{a} 923 \mathrm{~b} 448 \mathrm{~b} 7}$

Gillibrand, K., Carper, T. R., Coons, C. A., Franken, A., Shaheen, J., Merkley, J. A.... Harris, K. D. (2017, April 3). Letter to Secretary Kelly and Secretary Price.

Washington, D.C.: United States Senate. Retrieved from https://www.gillibrand.senate.gov/news/press/release/2017/04/04/gillibrand-leads-15senators-in-letter-to-trump-administration-requesting-information-on-childrenseparated-from-deported-parents-as-a-result-of-uptick-in-immigration-enforcement-1

Grieco, E. M., Acosta, Y. D., De La Cruz, G. P., Gambino, C., Gryn, T., Larsen, L. J., Trevelyan, E. N., \& Walters, N.P. (2012). The foreign born population in the United States: 2010: American community survey reports. Washington, D.C.: U.S. Census Bureau. Retrieved from https://www.census.gov/prod/2012pubs/acs-19.pdf

Immigrant Legal Resource Center. (2017). Family preparedness planning. Retrieved from https://www.ilrc.org/family-preparedness-plan 
Institute for Women in Migration. (2017). A brief guide for families, organizations, and public officials: Resources to inform, support, and prepare families for a possible return to Mexico. Retrieved from http://impactodemedidas.imumi.org/ingles/

Kandel, W. A. (2017, January 18). Unaccompanied alien children: An overview. Retrieved from https://fas.org/sgp/crs/homesec/R43599.pdf

Koball, H., Capps, R., Hooker, S., Perreira, K., Campetella, A., Pedroza, J. M., Monson, W., \& Huerta, S. (2015). Health and social service needs of U.S. citizen children with detained or deported immigrant parents. Washington, D.C.: Migration Policy Institute. Retrieved from http://www.migrationpolicy.org/research/health-and-socialservice-needs-us-citizen-children-detained-or-deported-immigrant-parents

Lacayo, E. (2011). One year later: A look at SB 1070 and copycat legislation. National Council of La Raza. Retrieved from http://publications.unidosus.org/handle/123456789/666

Lincroft, Y. (2013). The Reuniting Immigrant Families Act: A case study on California's Senate Bill 1064. Retrieved from http://cssr.berkeley.edu/cwscmsreports/LatinoPracticeAdvisory/LEGAL_State/The\% 20reuniting\%20immigrant\%20families\%20act A\%20case\%20study.pdf

Lincroft, Y., \& Borelli, K. (2009). A social worker's toolkit for working with immigrant families: A child welfare flowchart. Retrieved from https://ncwwi.org/files/A_SWers_Tool_Kit_for_Working_with_Immigrant_Families. pdf

Liptak, A. (2012, June 25). Blocking parts of Arizona law, justices allow its centerpiece. Retreived from the New York Times website https://www.nytimes.com/2012/06/26/us/supreme-court-rejects-part-of-arizonaimmigration-law.html

López, G., \& Bialik, K. (2017, May 3). Key findings about U.S. immigrants. Retrieved from Pew Research Center website http://www.pewresearch.org/facttank/2017/05/03/key-findings-about-u-s-immigrants/

Morton, J. (2011, Oct 24). Enforcement actions at or focused on sensitive locations [Memorandum]. Washington, D.C.: U.S. Customs and Immigration Enforcement. Retrieved from https://www.ice.gov/doclib/ero-outreach/pdf/10029.2-policy.pdf

National Immigration Law Center [NILC]. (2007). How to be prepared for an immigration raid. Retrieved from https://www.nilc.org/get-involved/communityeducation-resources/know-your-rights/immraidsprep_2007-02-27/

Reed, D., \& Karpilow, K. (2009). Understanding the child welfare system in California: A primer for service providers and policymakers (2nd ed.). Retrieved from http://www.phi.org/uploads/application/files/h31ef4xly0mtt9oa4lsv07oko48r6kg19g 6fisdm62qmymwbs5.pdf

Rojas-Flores, L., Clements, M. L., Hwang Koo, J., \& London, J. (2017). Trauma and psychological distress in Latino citizen children following parental detention and 
deportation. Psychological Trauma: Theory, Research, Practice, and Policy, 9(3), 352-361. doi: http://dx.doi.org/10.1037/tra0000177

Rosenblum, M. R., \& Ball, I. (2016). Trends in unaccompanied child and family migration from Central America. Retrieved from the Migration Policy Institute website https://www.migrationpolicy.org/research/trends-unaccompanied-child-andfamily-migration-central-america

Spivack, M. (2017, December 10). Rapid response training programs are aiming to document ICE activities. Retrieved from https://www.usatoday.com/story/news/2017/12/10/rapid-responders-aim-documentice-activities/939416001/

Support our Law Enforcement and Safe Neighbors Act, Arizona S. 1070, $49^{\text {th }}$ Leg. (2010). Retrieved from https://www.azleg.gov/legtext/49leg/2r/bills/sb1070s.pdf

Thronson, D. B. (2006). Choiceless choices: Deportation and the parent-child relationship. Nevada Law Journal, 6, 1165-1214.

Trevizo, P. (2016, January 2). Fewer parents of US-citizen kids being deported. Arizona Daily Star. Retrieved from http://tucson.com/news/fewer-parents-of-us-citizen-kidsbeing-deported/article_e45be3ba-b66e-5017-ab9c-9e0905b35c87.html

U.S. Census Bureau. (2017). 2016 American Community Survey. Available at https://factfinder.census.gov/faces/tableservices/jsf/pages/productview.xhtml?pid=A CS_10_1YR_B05009\&prodType=table

U.S. Customs and Border Protection. (2016, October 18). United States Border Patrol Southwest Family Unit Subject and Unaccompanied Alien Children Apprehensions Fiscal Year 2016. Retrieved from https://www.cbp.gov/newsroom/stats/southwestborder-unaccompanied-children/fy-2016.

U.S. Department of Homeland Security. (2012). U.S. Immigration and Customs Enforcment. Secure communities: Monthly Statistics through August 21, 2012 IDENT/IAFIS Interoperability. Retrieved from https://www.ice.gov/doclib/foia/scstats/nationwide interop stats-fy2012-to-date.pdf

U.S. Department of Homeland Security. (2017, September 27). Delegation of Immigration Authority Section 287 $(\mathrm{g})$ Immigration and Nationality Act. Retrieved from https://www.ice.gov/287g

U.S. Immigration and Customs Enforcement. (2013, August 23). Facilitating Parental Interests in the Course of Civil Immigration Enforcement Activities (No. 11064.1). Retrieved from https://cis.org/sites/default/files/Parental_Interest_Directive_8-23-13.pdf

U.S. Immigration and Customs Enforcement. (2016). Fiscal year 2016 ICE enforcement and removal operations report. Retrieved from https://www.ice.gov/sites/default/files/documents/Report/2016/removal-stats2016.pdf 
Wessler, S. F. (2011). Shattered families: The perilous intersection of immigration enforcement and the child welfare system. Applied Research Center. Retrieved from file:///C:/Users/vdecker/Downloads/ARC_Report_Shattered_Families_FULL_REPO $\underline{\text { RT Nov2011Release.pdf }}$

White House, Office of the Press Secretary [WH OPS]. (2017, January 25). Executive order: Enhancing public safety in the interior of the United States [Press release]. Retrieved from https://www.whitehouse.gov/the-pressoffice/2017/01/25/presidential-executive-order-enhancing-public-safety-interiorunited

WH OPS. (2014). Letter from the President -- Efforts to address the humanitarian situation in the Rio Grande Valley areas of our nation's Southwest border [Press release]. Retrieved from https://obamawhitehouse.archives.gov/the-pressoffice/2014/06/30/letter-president-efforts-address-humanitarian-situation-rio-grandevalle

Author note: Address correspondence to: Megan Finno-Velasquez PhD, School of Social Work, New Mexico State University, 11024 Montgomery Blvd. NE, PMB \#300, Albuquerque, NM 87111. Email: $\underline{\text { mfv@nmsu.edu }}$ 